\title{
Can Broadly Neutralizing HIV-1 Antibodies Help Achieve an ART-Free Remission?
}

\author{
Denise C. Hsu ${ }^{1,2}$, John W. Mellors ${ }^{3}$ and Sandhya Vasan ${ }^{1,2 *}$ \\ 1 U.S. Military HIV Research Program, Walter Reed Army Institute of Research, Silver Spring, MD, United States, ${ }^{2}$ Henry M. \\ Jackson Foundation for the Advancement of Military Medicine, Bethesda, MD, United States, ${ }^{3}$ Division of Infectious \\ Diseases, Department of Medicine, University of Pittsburgh, Pittsburgh, PA, United States
}

\section{OPEN ACCESS}

Edited by:

Philipp Schommers,

University of Cologne, Germany

Reviewed by:

Anthony DeVico,

University of Maryland, United States

Marina Caskey,

The Rockefeller University,

United States

Susan Zolla-Pazner,

Icahn School of Medicine at Mount

Sinai, United States

*Correspondence:

Sandhya Vasan

SVasan@hivresearch.org

Specialty section:

This article was submitted to Vaccines and Molecular Therapeutics, a section of the journal

Frontiers in Immunology

Received: 15 May 2021 Accepted: 25 June 2021

Published: 12 July 2021

Citation:

Hsu DC, Mellors JW and Vasan S (2021) Can Broadly Neutralizing HIV-1 Antibodies Help Achieve an ART-Free Remission?

Front. Immunol. 12:710044. doi: 10.3389/fimmu.2021.710044
Many broadly neutralizing antibodies (bnAbs) targeting the HIV-1 envelope glycoprotein are being assessed in clinical trials as strategies for HIV-1 prevention, treatment, and antiretroviral-free remission. BnAbs can neutralize HIV-1 and target infected cells for elimination. Concerns about HIV-1 resistance to single bnAbs have led to studies of bnAb combinations with non-overlapping resistance profiles. This review focuses on the potential for bnAbs to induce HIV-1 remission, either alone or in combination with latency reversing agents, therapeutic vaccines or other novel therapeutics. Key topics include preliminary activity of bnAbs in preclinical models and in human studies of HIV-1 remission, clinical trial designs, and antibody design strategies to optimize pharmacokinetics, coverage of rebound-competent virus, and enhancement of cellular immune functions.

Keywords: broadly neutralizing HIV-1 antibody, HIV remission, HIV cure, HIV immunotherapy, HIV therapeutics

\section{INTRODUCTION}

Antiretroviral therapy (ART) has dramatically reduced the morbidity and mortality associated with human immunodeficiency virus type-1 (HIV-1) infection by suppressing viral replication $(1,2)$ but ART does not cure HIV-1 because of long-lived cells carrying replication-competent (intact) proviruses (3-5). Viral rebound occurs within weeks in most people with HIV-1 (PWH) who discontinue ART, including those who initiate ART early during acute infection with long-term successful suppression of plasma viremia measured as HIV-1 RNA (6, 7). Additionally, there are barriers to universal ART uptake that include toxicities, stigma, and the need for lifelong adherence (8-10). Therefore, alternative ART-free strategies that confer durable viral suppression, prevent disease progression, and avoid drug resistance are highly desirable $(11,12)$. Proposed minimal target profiles for these strategies include the ability to maintain plasma HIV-1 RNA below the level at which transmission occurs, for at least 2 years, and be generally safe and tolerated (13). 
Broadly neutralizing antibodies target specific vulnerable sites on the HIV-1 envelope, mediate neutralization and target infected cells for elimination. In this review, we will focus on the potential for bnAbs to induce antiretroviral-free HIV-1 control, either alone or in combination with latency reversing agents, immune activating agents, therapeutic vaccines or other novel therapeutics.

\section{BROADLY NEUTRALIZING ANTIBODIES IN CLINICAL DEVELOPMENT}

Multiple bnAbs that exhibit breath and potency against epitopes on the HIV-1 envelope trimer are currently being assessed in clinical trials for HIV-1 prevention, treatment as well as remission induction. The targeted areas on HIV-1 envelope (see Figure 1) include the CD4-binding site (CD4bs) on gp120 [VRC01 (14); VRC01-LS (15), 3BNC117 (16), 3BNC117-LS (17), VRC07-523LS (18) and N6LS (19)]; the glycan-dependent epitopes on V1/V2 (PGDM1400 (20) and CAP256V2LS (21) as well as V3 loops (10-1074 (22), 10-1074-LS (17), PGT121 (23) and PGT121.414.LS); the linear epitopes in the membraneproximal external region (MPER) on gp41 [10E8VLS $(24,25)]$. Other bnAbs with high potency and breadth that have not yet entered clinical trials include antibodies targeting the gp120-gp41 interface (26) and the N49 lineage of CD4bs bnAbs $(27,28)$.

A number of clinical trials have shown that bnAbs (including VRC01, 3BNC117, 10-1074, VRC01-LS, VRC07-523LS, PGT121 and N6LS) are safe and well tolerated (29-38). Serious adverse events are rare but have been reported. A phase 1 study evaluating the subcutaneous administration of 10E8VLS alone or concurrently with VRC07-523LS in healthy adults was paused and the administration of 10E8VLS terminated due to local reactogenicity. Seven of 8 recipients of 10E8VLS experienced erythema and induration within 24 hours and a biopsy from 1 participant with induration demonstrated panniculitis (39).

The utility of bnAbs for HIV prevention have been reviewed extensively (40-42) and thus will not be a focus of this article. The recently completed Antibody Mediated Protection (AMP) trials, 2 parallel phase $2 \mathrm{~b}$ multicenter, randomized, double-blind, placebo-controlled trials involving over 4600 participants and over 3000 recipients of VRC01, every 8 weeks for 20 months have further demonstrated the safety, feasibility and scalability of intravenous bnAb infusion (43). Though VRC01 did not prevent overall HIV-1 acquisition, it did reduce the acquisition of viruses highly sensitive (an $80 \%$ inhibitory concentration, IC80 of $<1 \mu \mathrm{g} / \mathrm{mL}$ ) to VRC01, emphasizing the importance of breath and potency for bnAb efficacy.

In $\mathrm{PWH}$ and plasma viremia, bnAb monotherapy leads to transient reductions in HIV-1 RNA of $\sim 1.5 \log _{10}$ copies/mL (in the absence of pre-existing resistance), with mean HIV-1 RNA reductions of $1.48,1.14,1.52$ and $1.7 \log _{10}$ copies/mL for $3 \mathrm{BNC117}$, VRC-01, 10-1074 and PGT121, respectively (30-32, 36). These safety and antiviral activity data supported the investigation of bnAbs as potential therapeutics for HIV-1. The two main therapeutic applications that are in clinical evaluations are the use of bnAbs in place of current antiretroviral regimens to maintain viral suppression and the use of bnAb as part of a therapeutic combination to target and eliminate the HIV-1 reservoir.

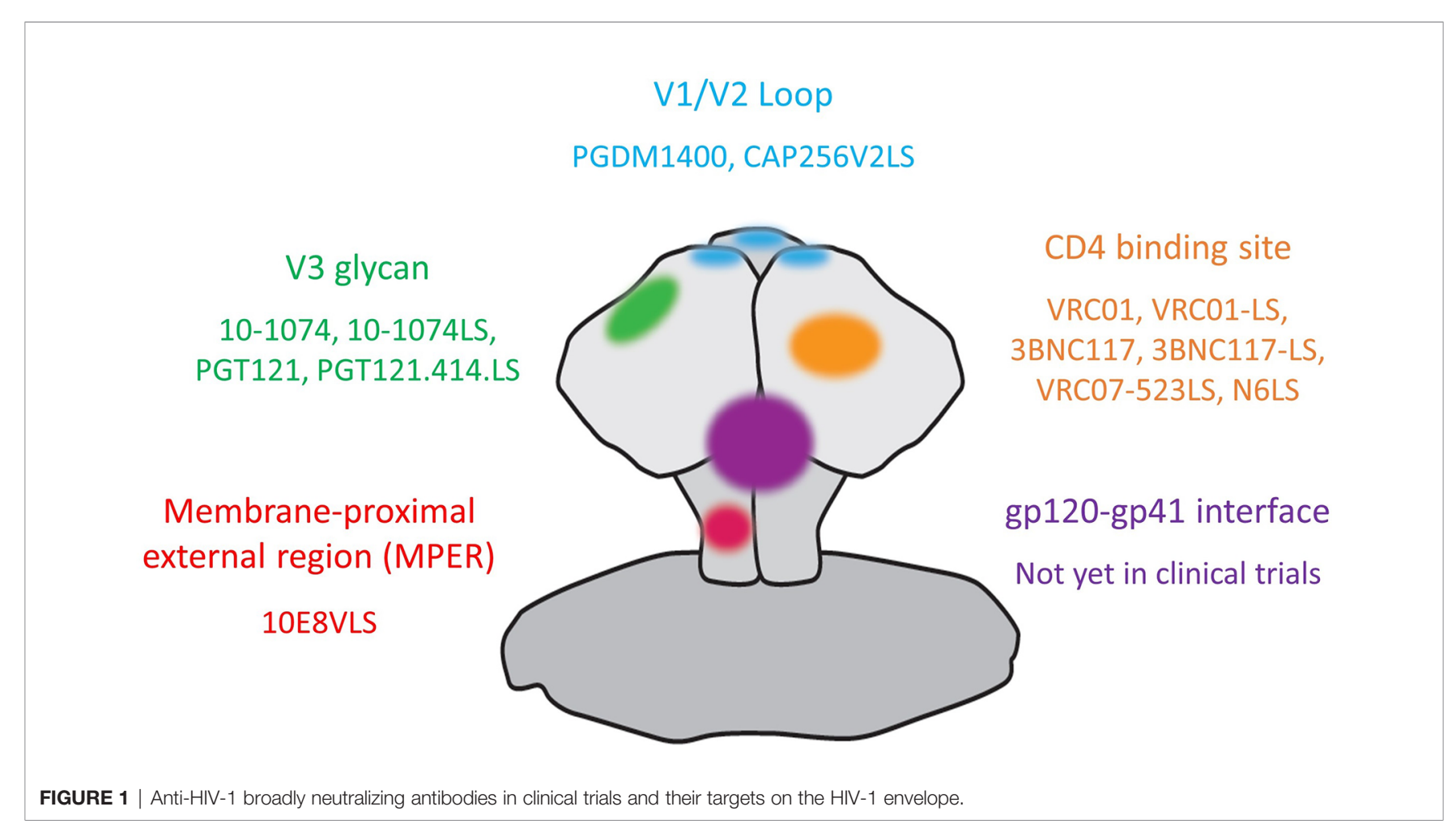




\section{THE USE OF BNAB IN PLACE OF ART TO MAINTAIN VIRAL SUPPRESSION}

The potential of bnAbs in maintaining viral suppression during analytical treatment interruption (ATI) has been assessed in a number of clinical trials. When 3BNC117 was administered during ATI to PWH with undetectable plasma HIV-1 RNA while on ART and with 3BNC117-sensitive outgrowth viruses, viral rebound was delayed to 8.4 weeks when compared to 2.6 weeks in matched historical controls. In the majority of participants, emerging viruses showed 3BNC117 resistance, indicating bnAb selection of escape variants. However, $30 \%$ of participants remained suppressed until 3BNC117 levels waned below $20 \mu \mathrm{g} / \mathrm{mL}$, and the viruses emerging in all but one of these participants showed no apparent resistance to $3 \mathrm{BCN} 117$, suggesting failure of bnAb escape over a period of 9-19 weeks (44). In contrast, when $3 \mathrm{BNC} 117$ was administered to PWH at 24 weeks, 12 weeks and 2 days before ATI and 3 weeks after ATI, without pre-selection for $3 \mathrm{NBC} 117$ sensitivity, the time to rebound was strongly influenced by the neutralization sensitivity of the pre-treatment viruses, 3.6 vs 9.2 weeks in those with resistant vs sensitive viruses, respectively (45).

In 2 single arm clinical trials, AIDS Clinical Trials Group (ACTG) A5340, and National Institutes of Health (NIH) 15-I0140, VRC01 during ATI was associated with a higher proportion of participants with undetectable HIV-1 RNA at 4 weeks post ATI when compared with historical controls. However, the difference was no longer significant at 8 weeks. VRC01 exerted pressure on the rebounding viruses, resulting in selection for preexisting and emerging bnAb-resistant viruses (46).

The aforementioned studies involved participants with treated chronic HIV-1 infection. PWH who initiated ART during acute HIV-1 infection (AHI) have smaller (47-49) and less diverse viral reservoirs $(50,51)$ as well as more preserved immune responses and thus may potentially display more favorable responses to bnAbs. VRC01 infusions during ATI in PWH who initiated ART during AHI did not significantly delay time to viral rebound of $>20$ copies $/ \mathrm{mL}$ but did delay time to viral rebound of $>1000$ copies $/ \mathrm{mL}$, at a median of 33 days in VRC01 recipients when compared to 14 days in placebo recipients (52). Importantly, neutralization sensitivity was similar after viral rebound when compared to at the time of AHI diagnosis, indicating the lack of selection for VRC01 resistance during ATI. This was most likely secondary to the near-absence of diversity among these participants' sequences and short duration of viral replication due to prompt ART initiation. Consistent with studies in chronic HIV-1 infection, participants with strains most sensitive to VRC01 rebounded later. Interestingly, viral rebound occurred while the average serum VRC01 level was 50 times higher than in vitro IC80 values, suggesting that the VRC01 concentrations achieved were therapeutically insufficient. This may be a result of inadequate levels or speed of VRC01 penetration into tissue reservoirs, off target protein binding, or other factors, emphasizing that in vitro IC50 orIC80 values do not necessarily translate to therapeutic concentrations in humans (53).
Collectively, these clinical trials indicate that bnAb monotherapy does not have sufficient breadth to prevent rebound in most individuals. However, in the setting of adequate neutralization breadth to cover rebound competent viruses, bnAbs have the potential to maintain viral suppression during ATI as long as therapeutic levels are maintained in plasma and tissues, although further studies are needed to define adequate therapeutic levels.

\section{MECHANISMS TO IMPROVE POTENTIAL FOR BNABS TO SUPPRESS VIRAL REPLICATION}

\section{Increasing Half-Life and Potency}

The current requirement for frequent dosing (monthly) reduces the appeal of bnAbs to maintain ART-free viral suppression. Thus, two amino acid mutations (methionine-to-leucine substitution and an asparagine-to-serine substitution at amino acid positions 428 and 434, respectively, collectively referred to as "LS") have been introduced into the fragment crystallizable $(\mathrm{Fc})$-region of a number of bnAbs to improve affinity to the neonatal Fc-receptor (FcRn), leading to recirculation following cellular endocytosis and thereby extending the in vivo half-life $(15,17,54)$.

In non-human primates (NHP), the LS substitution extended serum half-life by 2-3 fold (17) and also resulted in longer periods of protection against repeated mucosal challenges with Simian/ Human Immunodeficiency Virus (SHIV), expressing HIV-1 envelope on a SIV backbone, with medians of 14.5 vs 8,27 vs 12.5 and 17 vs 13 weeks for VRC01-LS, 10-1074-LS and 3BC117LS, respectively when compared to the unmodified parental bnAb $(17,55)$. In people without HIV, the LS substitution extended serum half-life of VRC01 from 15 to 71 days (34). Serum half-life after intravenous infusion was 38 days for VRC07-523LS (35) and 44 days for N6LS (38). Pharmacokinetics data for 3BNC117-LS (NCT03254277), 10-1074LS (NCT03554408), PGT121.414.LS (NCT04212091) and CAP256V2LS (NCT04408963) are forthcoming, and the impact of LS mutations on bnAb half-life in tissues is yet to be quantified.

Other mutations to extend half-life have also been reported, including the Met252Tyr, Ser254Thr, and Thr256Glu (YTE) substitution that is associated with a 4-fold increase in serum half-life $(56,57)$. However, YTE substitution also reduces ADCC activity of the antibody (56), which potentially reduces its utility in HIV remission induction strategies that will likely require ADCC.

Subcutaneous administration of bnAb by direct needle and syringe injection obviates the need for venous access and volumetric pump infusion and is thus more scalable for widespread use. However, when compared with intravenous infusion, subcutaneous injections of VRC01, VRC01-LS, VRC07-523LS and N6LS showed markedly reduced maximal serum concentration $\left(\mathrm{C}_{\max }\right)$ and delayed time to maximal concentration $\mathrm{T}_{\text {MAX }}(29,34,35,38)$. 
Next-generation sequencing, computational bioinformatics, and structure-guided design can be employed to modify bnAbs to enhance neutralization potency and breadth. This approach was applied to VRC01 and resulted in the development of VRC07-523-LS, that is over 5-fold more potent than VRC01 and neutralized $96 \%$ of a panel of $171 \mathrm{HIV}-1$ pseudotyped viruses in vitro (18).

\section{Addressing the Issue of bnAb Activity, Breadth and Resistance}

Certain HIV-1 strains are intrinsically resistant to bnAbs targeting specific epitopes. BnAbs targeting V3 glycans, including 10-1074 and PGT121, have little to no neutralizing activity against CRF01_AE and can only neutralize a minority of Clade D strains (22). In contrast, bnAbs targeting the V1/V2 loop have suboptimal activity against Clade B strains, with PGDM1400 neutralizing 70\% (20) and CAP256-VRC26.25 neutralizing only 15\% (58). Thus, data regarding the major prevalent subtypes for a particular geographic location must be considered in the selection of bnAbs.

In PWH with plasma viremia, bnAb mediated HIV-1 RNA reductions were mostly observed in those with sensitive HIV-1 strains. Furthermore, reduction in sensitivity developed within weeks of monotherapy, due to expansion of pre-existing resistant viruses or selection of new resistant variants $(30-32,36)$. Screening for pre-existing resistant variants is especially relevant for clinical trials assessing the utility of bnAbs during ATI. BnAb sensitivity of virus in plasma can be readily determined in participants with viremia; whereas in participants on suppressive ART, bnAb sensitivity can be determined using HIV-1 enveloped pseudovirus derived from proviral DNA in PBMC or directly using viruses from outgrowth cultures $(31,44,59)$. However, these assays are labor intensive, impractical for widespread implementation, and may not capture the spectrum of minor viral variants that could emerge $(60,61)$.

An approach to expand neutralization coverage is to use bnAbs targeting different HIV-1 envelope epitopes in combination. Combinations of three and four bnAbs can neutralize $98-100 \%$ of viruses from a diverse panel of 125 Envpseudotyped viruses in vitro $(62,63)$. In clinical trials, the combination of 3BNC117 and 10-1074 was safe and generally well tolerated and pharmacokinetics were similar to when these bnAbs were administered as monotherapy $(61,64)$.

Co-administration of $3 \mathrm{BNC} 117$ and $10-1074$ to $\mathrm{PWH}$ and plasma viremia resulted in an average $1.65 \log _{10}$ copies/mL reduction in HIV-1 RNA. The four participants with dual antibody-sensitive viruses had greater and more prolonged HIV-1 RNA reduction (average of $2.05 \log _{10}$ copies/mL for over 3 months). Suppression to undetectable levels was seen in one participant with low (730 copies/mL) pre-bnAb HIV-1 RNA. In 3 of the 4 initially sensitive participants, rebound viruses were resistant to 10-1074, but remained sensitive to $3 \mathrm{BNC117}$ (as the shorter half-life of 3BNC117 resulted in a tail of 10-1074 monotherapy) (60). Thus, in PWH with plasma viremia, dual bnAbs are not sufficient to suppress viremia to undetectable levels.

In contrast, co-administration of 3BNC117 and 10-1074 during ATI to PWH who had undetectable plasma HIV-1
RNA while on ART and outgrowth viruses that were sensitivity to both 3BNC117 and 10-1074, maintained viral suppression for extended durations. The median time to rebound was 21 weeks compared to 8.4 weeks with $3 \mathrm{BNC117}$ monotherapy and 2.3 weeks for historical controls. In participants with no detectable resistant viruses pre-infusion, viral rebound occurred when the levels of bnAb waned. Rebound viruses were resistant to $10-1074$, but remained sensitive to $3 \mathrm{BNC117}$ (due to the shorter half-life of 3BNC117) but none developed viruses resistant to both antibodies (61). This study supports that bnAbs used in combination can maintain longterm viral suppression in $\mathrm{PWH}$ with antibody-sensitive viruses as long as therapeutic levels are maintained. A number of clinical trials assessing the efficacy of combinations of bnAbs in maintaining viral suppression during ATI are currently ongoing (Table 1). Differential clearance of bnAbs used in combination that could result in a tail of bnAb monotherapy remains an issue to be addressed by thorough understanding of bnAb pharmacokinetics and interactions in clinical trials.

\section{Expanding bnAb Breadth}

Newer technologies allow for the construction of antibodies with two, three, or four different binding sites on a single molecule. Targeting multiple HIV-1 envelope epitopes in a single bnAb molecule reduces the risk of developing viral resistance during periods of essential monotherapy due to differential half-lives of combination bnAbs, simplifies manufacturing and downstream product development and thus scalability. The 10E8V2.0/ ibalizumab bispecific ab, generated using CrossMAbs technology, neutralized $100 \%$ of a panel of $118 \mathrm{HIV}-1$ pseudotyped viruses in vitro with mean IC50 values of 0.002 $\mu \mathrm{g} / \mathrm{mL}$. Furthermore, it also protected humanized mice against repeated intraperitoneal HIV-1 $1_{\text {JR-CSF }}$ challenges (65). Currently, a phase I dose-escalation study on the safety, tolerability, pharmacokinetics, and anti-HIV-1 activity of the 10E8.4/ ibalizumab bispecific Ab is in progress (NCT03875209).

Tri-specific abs have also been generated using knob-in-hole heterodimerization to pair a single arm derived from a normal immunoglobulin ( $\operatorname{IgG}$ ) with a double-arm generated in the cross-over dual variable Ig-like proteins (CODV-Ig). Two lead tri-specific Ab, N6/PGDM1400-10E8v4 and VRC01/ PGDM1400-10E8v4 were able to neutralize 207 and 204 of 208 pseudotyped viruses in vitro, respectively. When NHP were challenged intrarectally with a mix of $\mathrm{SHIV}_{325 \mathrm{c}}$ (resistant to

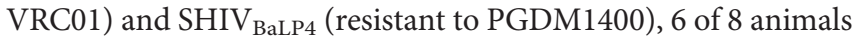
infused with VRC01 alone and 5 of 8 animals infused with PGDM1400 became infected. In contrast, none of the 8 animals infused with VRC01/PGDM1400-10E8v4 trispecific Ab were infected (66). This demonstrated that tri-specific ab conferred protection against viruses that otherwise showed resistance to single parental bnAbs. The VRC01-LS/PGDM1400-10E8v4 trispecific ab (SAR441236) is currently being evaluated in a dose escalation study to determine safety, pharmacokinetics and anti-HIV-1 activity (NCT03705169).

It is anticipated that the modified versions of $10 \mathrm{E} 8$ used in the aforementioned bi- and tri-specific bnAbs will not recapitulate 
TABLE 1 | Ongoing clinical trials of bnAb as part of HIV-1 therapeutic or remission strategy.

\begin{tabular}{|c|c|c|c|c|c|}
\hline BnAb & Target site & $\begin{array}{c}\text { Additional } \\
\text { Intervention(s) }\end{array}$ & Study population & Study Endpoints & $\begin{array}{l}\text { Clinicaltrials.gov } \\
\text { identifier }\end{array}$ \\
\hline \multicolumn{6}{|c|}{ Studies on antiviral effects of bnAbs } \\
\hline $\begin{array}{l}\text { VRC01-LS or } \\
\text { VRC07-523LS }\end{array}$ & CD4bs & & Adults with HIV-1 and plasma viremia & $\begin{array}{l}\text { Safety, PK and effects on plasma } \\
\text { viremia }\end{array}$ & NCT02840474 \\
\hline $\begin{array}{l}3 \mathrm{BNC} 117+10- \\
1074\end{array}$ & CD4bs, V3 glycans & & Adults with HIV-1 and plasma viremia & $\begin{array}{l}\text { Safety and effects on plasma } \\
\text { viremia }\end{array}$ & NCT03571204 \\
\hline $\begin{array}{l}\text { 3BNC117-LS + } \\
\text { 10-1074-LS }\end{array}$ & CD4bs, V3 glycans & & Adults with HIV-1 and plasma viremia & $\begin{array}{l}\text { Safety, PK and effects on plasma } \\
\text { viremia }\end{array}$ & NCT04250636 \\
\hline $\begin{array}{l}\text { VRC07-523LS + } \\
\text { PGT121 + } \\
\text { PGDM1400 }\end{array}$ & $\begin{array}{l}\text { CD4bs, V3 glycans, } \\
\text { V1N2 loop }\end{array}$ & & Adults with HIV-1 and plasma viremia & $\begin{array}{l}\text { Safety, PK and effects on plasma } \\
\text { viremia }\end{array}$ & NCT03205917 \\
\hline 10E8.4/iMab & MPER, CD4 & & Adults with HIV-1 and plasma viremia & $\begin{array}{l}\text { Safety, PK and effects on plasma } \\
\text { viremia }\end{array}$ & NCT03875209 \\
\hline SAR441236 & $\begin{array}{l}\text { Trispecific Ab } \\
\text { targeting CD4bs, v2 } \\
\text { loop, MPER }\end{array}$ & & Adults with HIV-1 and plasma viremia & $\begin{array}{l}\text { Safety, PK and effects on plasma } \\
\text { viremia }\end{array}$ & NCT03705169 \\
\hline VRC01 & CD4bs & & $\begin{array}{l}\text { Adults at the diagnosis of acute HIV-1 } \\
\text { infection, in addition to ART }\end{array}$ & $\begin{array}{l}\text { Safety and effects on plasma } \\
\text { viremia }\end{array}$ & NCT02591420 \\
\hline VRC01 & CD4bs & & Infants with HIV-1, in addition to ART & $\begin{array}{l}\text { Safety, PK and effects on plasma } \\
\text { viremia }\end{array}$ & NCT03208231 \\
\hline 3BNC117 & CD4bs & $\begin{array}{l}\text { Albuvirtide (Fusion } \\
\text { inhibitor) }\end{array}$ & Adults with multi-drug resistant HIV-1 & Effects on plasma viremia & NCT04560569 \\
\hline \multicolumn{6}{|c|}{ Studies on efficacy in maintaining viral suppression during ATI } \\
\hline $\begin{array}{l}\text { 3BNC117 + 10- } \\
1074\end{array}$ & CD4bs, v3 glycans & & Adults with HIV-1, on ART & $\begin{array}{l}\text { Effects on the latent reservoir, } \\
\text { impact on viral rebound and safety }\end{array}$ & NCT03526848 \\
\hline $\begin{array}{l}3 \mathrm{BNC} 117+10- \\
1074\end{array}$ & CD4bs, V3 glycans & & $\begin{array}{l}\text { Adults with HIV-1, on ART, initiated during } \\
\text { primary HIV-1 infection }\end{array}$ & Safety and impact on viral rebound & NCT03571204 \\
\hline $\begin{array}{l}\text { VRC01-LS + 10- } \\
1074\end{array}$ & CD4bs, V3 glycans & & $\begin{array}{l}\text { Children with antepartum or peripartum } \\
\text { HIV-1 infection, on ART, initiated early } \\
\text { after diagnosis }\end{array}$ & $\begin{array}{l}\text { Safety, impact on viral rebound } \\
\text { and PK }\end{array}$ & NCT03707977 \\
\hline $\begin{array}{l}\text { VRC01+10- } \\
1074\end{array}$ & CD4bs, V3 glycans & & Adults with HIV-1, on ART & Safety and impact on viral rebound & NCT03831945 \\
\hline $\begin{array}{l}\text { 3BNC117-LS + } \\
\text { 10-1074-LS }\end{array}$ & CD4bs, V3 glycans & & $\begin{array}{l}\text { Adults with } \mathrm{HIV}-1 \text {, on } \mathrm{ART} \text {, initiated during } \\
\text { primary HIV-1 infection }\end{array}$ & Safety and impact on viral rebound & NCT04319367 \\
\hline $\begin{array}{l}\text { VRC07-523LS + } \\
\text { PGT121 + } \\
\text { PGDM1400 }\end{array}$ & $\begin{array}{l}\text { CD4bs, V3 glycans, } \\
\text { V1N2 loop }\end{array}$ & & Adults with HIV-1, on ART & $\begin{array}{l}\text { Safety, PK and impact on viral } \\
\text { rebound }\end{array}$ & NCT03721510 \\
\hline 3BNC117 & CD4bs & $\begin{array}{l}\text { Albuvirtide (Fusion } \\
\text { inhibitor) }\end{array}$ & Adults with HIV-1, on ART & Impact on viral rebound & NCT03719664 \\
\hline $\begin{array}{l}\text { 3BNC117-LS + } \\
\text { 10-1074-LS }\end{array}$ & CD4bs, V3 glycans & $\begin{array}{l}\text { Lenacapavir (capsid } \\
\text { inhibitor) }\end{array}$ & Adults with HIV-1, on ART & $\begin{array}{l}\text { Safety, impact on viral rebound } \\
\text { and PK }\end{array}$ & NCT04811040 \\
\hline VRC07-523LS & CD4bs & $\begin{array}{l}\text { Long-acting } \\
\text { cabotegravir }\end{array}$ & Adults with HIV-1, on ART & $\begin{array}{l}\text { Safety and impact on viral rebound } \\
\text { and PK }\end{array}$ & NCT03739996 \\
\hline \multicolumn{6}{|c|}{ Studies on bnAbs in combination with additional interventions to target and eliminate the viral reservoir } \\
\hline 3BNC117 & CD4bs & Romidepsin (LRA) & $\begin{array}{l}\text { Adults at the diagnosis of HIV-1 infection, } \\
\text { in addition to ART }\end{array}$ & $\begin{array}{l}\text { Safety, effects on plasma viremia } \\
\text { and the latent reservoir }\end{array}$ & NCT03041012 \\
\hline 3BNC117 & CD4bs & Romidepsin & Adults with HIV-1, on ART & $\begin{array}{l}\text { Safety, impacts on viral rebound } \\
\text { and the latent reservoir }\end{array}$ & NCT02850016 \\
\hline VRC07-523LS & CD4bs & Vorinostat (LRA) & Adults with HIV-1, on ART & Safety, effects on viral reservoir & NCT03803605 \\
\hline $\begin{array}{l}3 \mathrm{BNC} 117+10- \\
1074\end{array}$ & CD4bs, V3 glycans & $\begin{array}{l}\text { Lefitolimod (TLR9 } \\
\text { agonist) }\end{array}$ & Adults with HIV-1, on ART & Safety and impact on viral rebound & NCT03837756 \\
\hline $\begin{array}{l}\text { VRC07-523LS + } \\
10-1074\end{array}$ & CD4bs, V3 glycans & $\begin{array}{l}\mathrm{N}-803 \text { (IL-15 } \\
\text { superagonist) }\end{array}$ & Adults with HIV-1, on ART & $\begin{array}{l}\text { Safety, impacts on viral rebound } \\
\text { and the latent reservoir, PK }\end{array}$ & NCT04340596 \\
\hline $\begin{array}{l}3 \mathrm{BNC} 117+10- \\
1074\end{array}$ & CD4bs, V3 glycans & $\begin{array}{l}\text { Pegylated Interferon } \\
\text { alpha } 2 \mathrm{~b}\end{array}$ & Adults with HIV-1, on ART & $\begin{array}{l}\text { Safety, NK cell activity and impact } \\
\text { on viral rebound }\end{array}$ & NCT03588715 \\
\hline $\begin{array}{l}\text { VRC07-523LS + } \\
10-1074\end{array}$ & CD4bs, V3 glycans & $\begin{array}{l}\text { HIV DNA vaccine, } \\
\text { HIV MVA vaccine, } \\
\text { lefitolimod }\end{array}$ & Adults with HIV-1, on ART & $\begin{array}{l}\text { Safety, proportion with post } \\
\text { treatment control, immunogenicity }\end{array}$ & NCT04357821 \\
\hline $10-1074$ & V3 glycans & $\begin{array}{l}\text { HIV RNA vaccine, } \\
\text { romidepsin }\end{array}$ & Adults with HIV-1, on ART & $\begin{array}{l}\text { Safety, impacts on viral rebound } \\
\text { and the latent viral reservoir, } \\
\text { immunogenicity }\end{array}$ & NCT03619278 \\
\hline
\end{tabular}


the local reactogenicity associated with 10E8VLS due to differences in amino acid sequences as well as antibody-antigen interactions between the bivalent 10E8VLS and the monovalent 10E8.4 arm of the bi- or tri-specific bnAbs. Due to their novel structures, recombinant multi-specific Abs have a higher theoretical possibility of inducing anti-drug Abs. However, this has not been reported in the preliminary trials to date and will need to be confirmed in larger scale studies in humans.

\section{THE USE OF BNABS TO TARGET, CONTROL AND POTENTIALLY ELIMINATE THE VIRAL RESERVOIR}

\section{BnAbs Alone}

Data from rhesus macaques inoculated with SHIV suggest that bnAb when administered alone may induce sustained ART free remission (Table 2). When 3BNC117 and 10-1074 were administered to animals 3 days post intra-rectal SHIV $_{\mathrm{AD} 8-\mathrm{EO}}$ inoculation, plasma viremia was only detectable in 2 of 6 animals in the first month. Viral suppression was maintained for 8-25 weeks until bnAb levels waned. Importantly, 3 animals developed viral control. In a follow-on experiment, the same bnAb regimen was administered 3 days post intravenous SHIV $_{\text {AD8-EO }}$ inoculation. Plasma viremia was initially detected in all animals post inoculation (PI), but then declined to undetectable levels by 4 weeks post bnAb administration. Rebound occurred at 7-16 weeks PI when bnAb levels waned. Three of 7 animals developed post-rebound viral control. Subsequent CD8 T cell depletion in all 6 controllers resulted in increase in plasma viremia, suggesting a CD8 T cell dependent mechanism for control (67).
To evaluate the above strategy at a more clinically relevant post infection timepoint, $\mathrm{SHIV}_{\mathrm{AD} 8-\mathrm{EO}}$-infected monkeys were treated with bnAbs (10-1074 and 3BNC117) alone or with ART plus bnAbs starting at 2 weeks PI. In the bnAb alone group, bnAbs reduced plasma viremia overall, but only 1 animal achieved full plasma viral suppression. This animal later rebounded and subsequently regained control. Three other animals also controlled virus, but much later, at 90-150 weeks post infection. Viral rebound occurred in all animals in the ART plus bnAbs group when bnAb levels waned. Three animals developed post-rebound viral control at weeks 70-160. CD8 T cell depletion in controllers from both groups also led to transient increases in plasma viremia (68).

Therefore, bnAbs initiated on day 3 or day 14 PI resulted in CD8 $\mathrm{T}$ cells dependent viral control in about half the animals. However, the time required to develop viral control was much more protracted when the initiation of bnAbs were delayed. The authors speculated that though bnAbs administered early post infection suppressed viremia, very-low levels of antigen production likely persisted and in the presence of bnAbs stimulated immune complex formation and dendritic cell activation leading to the induction of CD8 $\mathrm{T}$ cell responses. Immune responses were further augmented during viral rebound, culminating in viral control.

There is little data in humans on the efficacy of bnAbs to induce $\mathrm{T}$ cell responses leading to viral control. In the study by Mendoza et al, in which a combination of 3NBC117 and 10-1074 was administered during ATI, increased Gag-specific CD8+ and CD4+ T cell responses were seen in 9/9 and 8/9 participants with sensitive viruses and prolonged viral suppression. The increases were attributed to both newly detectable reactivity to HIV-1 Gag epitopes and the expansion of pre-existing measurable responses

TABLE 2 | Non-human primate studies on the use of bnAbs to target, control and potentially eliminate the viral reservoir.

\begin{tabular}{|c|c|c|c|c|c|}
\hline & SHIV & $\begin{array}{c}\text { ART } \\
\text { initiation }\end{array}$ & $\mathrm{BnAb}$ & $\begin{array}{c}\text { Additional } \\
\text { Interventions }\end{array}$ & Outcome \\
\hline $\begin{array}{l}\text { Nishimura } \\
\text { et al. (67) }\end{array}$ & $\mathrm{SHIV}_{\mathrm{AD} 8-\mathrm{EO}}$ & No ART & $\begin{array}{l}\text { 3BNC117 }+10-1074 \text { at days } 3,10 \\
\text { and } 17 \mathrm{PI}\end{array}$ & & $\begin{array}{l}\text { Viral control in } 3 \text { of } 6 \text { animals from intra-rectal } \\
\text { and } 3 \text { of } 7 \text { animals from intravenous inoculation }\end{array}$ \\
\hline $\begin{array}{l}\text { Nishimura } \\
\text { et al. (68) }\end{array}$ & $\mathrm{SHIV}_{\mathrm{AD} 8-\mathrm{EO}}$ & 2 weeks post infection & $\begin{array}{l}\text { 3BNC117 + 10-1074 alone at weeks } \\
2,4 \text { and } 6 \text { PI or } \\
\text { ART initiation at week 2; 3BNC117 + } \\
\text { 10-1074 at weeks 9, } 11 \text { and 13; ART } \\
\text { discontinuation at week } 10\end{array}$ & & $\begin{array}{l}\text { Viral control in } 4 \text { of } 6 \text { animals in bnAb alone } \\
\text { arm in } 3 \text { of } 6 \text { animals in bnAb and ART arm }\end{array}$ \\
\hline $\begin{array}{l}\text { Borducchi } \\
\text { et al. (69) }\end{array}$ & $\mathrm{SHIV}_{\mathrm{SF} 162 \mathrm{P} 3}$ & 7 days post infection & PGT121 & TLR7 agonist & $\begin{array}{l}\text { No rebound in } 5 / 11 \text { animals and delay in } \\
\text { rebound when compared to controls ( } 112 \text { vs } \\
21 \text { days) }\end{array}$ \\
\hline $\begin{array}{l}\text { Hsu et al. } \\
(70)\end{array}$ & $\mathrm{SHIV}_{1157 \mathrm{ipd} 3 \mathrm{~N} 4}$ & 2 weeks post infection & PGT121 + N6-LS & TLR7 agonist & $\begin{array}{l}\text { Delay in rebound when compared to controls } \\
\text { (6 versus } 3 \text { weeks) }\end{array}$ \\
\hline $\begin{array}{l}\text { Barouch } \\
\text { et al. }(71)\end{array}$ & $\mathrm{SHIV}_{\mathrm{SF} 162 \mathrm{P} 3}$ & 12 months post infection & $\begin{array}{l}\text { PGT121 or its FC modified version } \\
\text { (GS9721) }\end{array}$ & TLR7 agonist & No rebound in $7 / 17$ animals \\
\hline $\begin{array}{l}\text { Whitney } \\
\text { et al. (72) }\end{array}$ & $\mathrm{SHIV}_{\mathrm{AD} 8}$ & 50 days post infection & $3 \mathrm{BNC} 117+10-1074$ & IL-15 superagonist & $\begin{array}{l}\text { No difference in time to rebound. Post-rebound } \\
\text { control in } 6 \text { of } 8 \text { animals }\end{array}$ \\
\hline $\begin{array}{l}\text { Barouch } \\
\text { et al. (73) }\end{array}$ & $\mathrm{SHIV}_{\mathrm{SF} 162 \mathrm{P} 3}$ & 9 days post infection & PGT121 & $\begin{array}{l}\text { TLR7 agonist, } \\
\text { Ad26/MVA vaccine }\end{array}$ & $\begin{array}{l}4 \text { of } 12 \text { PGT121+TLR7 agonisttreated animals } \\
\text { and } 4 \text { of } 10 \text { Ad26/MVA vaccine+PGT121 } \\
+ \text { TLR7 agonist-treated animals did not } \\
\text { rebound post treatment interruption. Only } 4 \text { of } \\
10 \text { Ad26/MVA vaccine+PGT121+TLR7 } \\
\text { agonist-treated animals remained viremic } 140 \\
\text { days post treatment interruption. }\end{array}$ \\
\hline
\end{tabular}


(74). However, whether the increase in responses contribute to viral control remains to be elucidated.

Data from human trials involving bnAbs infusions concurrent with ART [including VRC01 $(31,75)$ and 3BNC117 (45)] showed no measurable impact on the latent reservoir. The impact of bnAbs on the reservoir would likely be improved when used in combination with other strategies, including latency reversal agents to induce proviral activation and cell-surface expression of viral envelopes so that they can be targeted by bnAbs, immune activating agents to enhance anti-viral responses and Fc-mediated killing of infected cells, or therapeutic vaccination to stimulate $\mathrm{T}$ cell responses for viral control.

\section{BnAbs and Immune Activating Agents}

In the study by Borducchi et al., toll-like receptor 7 (TLR7) agonist was incorporated to induce innate immune activation and enhance anti-viral responses $(76,77)$. In this study, TLR7 agonist and PGT121 were administered in addition to ART (initiated at 7 days post $\mathrm{SHIV}_{\mathrm{SF} 162 \mathrm{P} 3}$ inoculation). ART was discontinued after antibody washout at week 130. Only 6 of 11 (55\%) animals that received PGT121+TLR7 agonist rebounded, at a median of 112 days vs 21 days in controls $(\mathrm{p}=0.0001)$ (69). Interestingly, no induction of CD8 $\mathrm{T}$ cell responses was seen. Importantly, in the animals that did not rebound, adoptive transfer experiments did not reveal infection of naïve hosts. Furthermore, SHIV RNA also remained undetectable after CD8 $\mathrm{T}$ cell depletion. These data suggest that the combination of immune stimulation with bnAb administration may potentially eliminate the viral reservoir.

In a follow-on study by Hsu et al., rhesus macaques inoculated with $\mathrm{SHIV}_{1157 \text { ipd3N4 }}$ were initiated on ART on day 14 to more closely mirror what is logistically feasible in humans. ART initiation was followed by the administration of TLR7 agonist and dual bnAbs (N6-LS and PGT121). ART was discontinued after antibody washout. Though TLR7 agonist and dual bnAbs delayed viral rebound by 2 -fold ( 3 vs 6 wks, $\mathrm{p}=0.024$ ), viral rebound occurred in all animals (70). The delay in ART initiation, the shorter duration of ART and the lower number of doses of bnAbs administered (ranging from 2-5 doses, limited by the development of anti-drug antibody) may have contributed to the reduction in efficacy when compared with the Borducchi et al. study.

In a recent study, Barouch et al., demonstrated in $\mathrm{SHIV}_{\mathrm{SF}_{1623^{-}}}$ infected animals that initiated ART 12 months after infection, TLR7 agonist and PGT121 or its Fc-modified version, GS-9721 prevented viral rebound in 7 of 17 animals following ART discontinuation. These data suggest that TLR7 agonist and bnAb administration is efficacious for ART-free remission of chronic SHIV infection (71).

Whitney et al. explored the use of N-803 [IL-15 superagonist that has been shown to increase NK and CD8 T cells in the peripheral blood as well as SHIV-specific CD8 T cells in lymphoid follicles (78-80)] in combination with 3BNC117 and 10-1074 in macaques on ART for chronic SHIV $\mathrm{AD}_{\mathrm{AD}}$ infection. ATI occurred after bnAb washout. Viral rebound occurred in all animals and no differences in time to rebound were seen between the active and control groups. However, post-rebound viral control occurred in 6 of 8 animals in the active group 4 months from the start of ATI (72).
Data regarding the effects of bnAbs in combination with additional strategies on the latent reservoir in humans is forthcoming. In a trial of 3BNC117 and romidepsin [a histone deacetylase inhibitor (81)], in $20 \mathrm{PWH}$ on ART, the addition of 3 BNC117 did not significantly reduce HIV-1 DNA or delay viral rebound when compared to romidepsin alone (82). A number of clinical trials, including 3BNC117+romidepsin (NCT03041012, NCT02850016), VRC07-523LS+vorinostat (NCT03803605), pegylated-interferon Alpha 2b+3BNC117+10-1074 (NCT03588715), lefitolimod (TLR9 agonist)+3BNC117+10-1074 (NCT03837756) and N-803+VRC07-523LS+10-1074 (NCT04340596) are currently on-going (Table 1).

\section{Use of bNabs With Vaccination}

The effects of immune stimulation (TLR agonism) and bnAbs may be further enhanced by the addition of therapeutic vaccine to induce anti-HIV-1 CD8 $\mathrm{T}$ cell responses. This strategy was explored in $\mathrm{SHIV}_{\mathrm{SF} 162 \mathrm{P} 3}$-infected rhesus macaques that were initiated on ART day 9 post infection. Following ART discontinuation, all control animals rebounded. All 12 of the Ad26/MVA vaccine+TLR7 animals also rebounded, but 3 developed post-rebound viral control. In contrast, only 8 of 12 of PGT121+TLR7 treated animals and 6 of 10 of Ad26/MVA vaccine +PGT121+TLR7 treated animals rebounded. Moreover, some animals exhibited post-rebound viral control so that by day 140 following ART discontinuation, only 4 of 10 of Ad26/MVA vaccine +PGT121+TLR7 treated animals have detectable viremia (73). Thus, combined TLR7 agonist, active and passive immunization resulted in both delayed viral rebound and post-rebound control following ART. This strategy is also being explored in an upcoming clinical trial involving therapeutic conserved element DNA vaccine+MVA vaccine+VRC07-523LS+10-1074+lefitolimod (NCT04357821) and ChAdOx/MVA HIV mosaic vaccine +3BNC117LS+10-1074LS+vesatolimod (ACTG5374) in PWH who initiated ART during acute HIV infection. Such human data is essential to determine whether results in NHP can be reproduced.

Data regarding the use of bnAbs to target, control and potentially eliminate the viral reservoir are largely from small NHP studies. However, there are differences between SHIVinfected NHP and PWH including lower viral diversity and higher rate of natural control in SHIV infection. Furthermore, efficacy of bnAbs is reduced with delay in bnAb administration or ART initiation, suggesting a narrow window of opportunity to intervene. Finally, a prolonged duration of viremia is also required for the observation of post treatment control. Thus, feasibility and translatability in PWH who started ART during chronic HIV infection is yet to be demonstrated.

\section{INCORPORATING LESSONS LEARNED INTO CLINICAL TRIAL DESIGN}

\section{The Use of bnAbs to Maintain Viral Suppression}

Available data demonstrated that bnAbs are generally safe and suggest that bnAbs can maintain viral suppression during ATI as long as the pre-existing viruses are sensitive and therapeutic 
levels are maintained. Judicious selection of bnAbs based on neutralization-sensitivity of the predominant variants in a given geographic location, screening for pre-existing resistance and the use of bnAbs in combination to increase breadth and coverage will minimize the selection of escape variants. These optimization strategies will need to be further assessed in phase II or III clinical trials involving participants with chronic HIV infection to determine longer term efficacy. The ultimate goal is to identify antibody combinations with adequate breath to cover for circulating variants to obviate the need for screening for pre-existing resistance, which is a major barrier to widespread use. When bnAbs are used in combination in the absence of ART, considerations must be given to differences in half-life of each respective bnAb. In addition to peripheral blood, collection of tissue samples including lymph node and gut biopsies should be incorporated into clinical trials to allow measurement of the levels of bnAbs so as to inform what constitutes therapeutic levels in reservoir sites.

The use of bnAbs with LS modifications will extend duration above therapeutic threshold and reduce infusion frequency. This, together with alternative routes of administration such as subcutaneous injection will facilitate scale-up and access. Data from clinical trials evaluating long-acting injectable anti-HIV drugs, including monthly intramuscular cabotegravir (integrase strand transfer inhibitor) and rilpivirine (nonnucleoside reversetranscriptase inhibitor) (83) or 6-monthly subcutaneous lenacapavir (capsid inhibitor) (84) are becoming available. Monthly intramuscular cabotegravir and rilpivirine demonstrated non-inferior viral suppression when compared to standard ART. The development of resistance is infrequent. However, injectionrelated adverse events were common ( $>80 \%$ of participants) but only infrequently led to medication withdrawal (83). Long acting ART will contend with bnAbs as preferred agents to maintain long-term viral suppression with infrequent dosing. Given that both strategies have pros and cons, usage and uptake will likely be driven by considerations including availability, local HIV-variant sensitivity profile, tolerability, relative cost and availability, and individual and local cultural preferences. While some may prefer a daily oral pill, others may prefer a less frequent schedule of administration. Dosage route, frequency, and potential for bnAbs self-administration will be important factors in this consideration.

\section{The Use of bnAbs to Induce HIV Remission}

$\mathrm{BnAbs}$ alone are unlikely to be adequate to eliminate the latent reservoir. A handful of NHP studies where bnAbs were used in combination with innate immune activating agents have shown promise. However, mechanisms for delay in viral rebound or post-rebound viral control have not been delineated. The strategy of innate stimulation, active and passive immunization are in the early stages of development and data is needed to inform decisions regarding optimal timing and order of administration of individual interventions to maximize therapeutic effects.

It is important to bear in mind that immune activating agents may potentially expand the reservoir through clonal proliferation. It remains possible that certain reservoir sites including the central nervous system may be exposed to latency activation and viral replication but little bnAb mediated anti-HIV-1 effects due to the blood brain barrier limiting bnAb penetrance. These questions can be addressed in NHP models where direct tissue sampling of the brain is more feasible. In parallel, clinical trials administering bnAb therapies can also monitor differential impact on bnAb therapies administered by varying routes on viral burden or cellular reservoirs in the cerebrospinal fluid relative to blood.

Data from NHP studies suggest that the opportunity to intervene may be narrow, with reduction in efficacy or substantial increase in time required to observe results when bnAb administration or ART initiation is delayed just by a few weeks. The MHRP RV217 prospective cohort involving seronegative high-incidence populations who underwent twiceweekly HIV-1 RNA testing estimated the eclipse phase (the time between HIV-1 infection and a diagnosable infection by nucleic acid testing) to be one week (85). Therefore, taking into account the time required to diagnose, screen and then enroll participants into a clinical trial, the earliest that interventions can realistically be administered is likely around 2 weeks post infection. The clinical trial NCT02591420 that explores the effects of VRC01 when administered at the time of diagnosis of AHI on the viral reservoir has just completed clinical follow-up, demonstrating that intervening early during HIV-1 infection is logistically feasible. However, the majority of PWH initiated ART during chronic infection and the impacts of these strategies in this setting are yet to be defined.

Though NHP studies demonstrated that post-rebound viral control is possible, a protracted period of viremia may be required prior to the development of control. The delicate balance between the utility of an extended ATI to observe post-rebound viral control versus the associated risks of transmission to sexual partners, symptomatic HIV disease, immune depletion, and emergence of new drug resistance mutation has generated much debate among researchers, ethicists and $\mathrm{PWH}$ (86-89). Research in delineating mechanisms and/or correlates for delay in viral rebound and sustained post-rebound viral control is urgently needed to reduce the reliance on extended ATI as an outcome measure.

BnAbs are generally safe and well tolerated and have been shown to maintain viral suppression in the setting of sensitive pre-treatment viruses. Mechanisms to improve antiviral effects and ease of use are becoming available. Thus, bnAbs used in combination have the potential to replace ART and obviate the need for high level adherence that is necessary for daily ART. The use of bnAbs as a component of combination strategies to target the reservoir has shown promise in NHP models. However, the window of opportunity to intervene for maximal effect may be narrow. A remission strategy should be effective across the spectrum of HIV infection. Thus, much work needs to be done to answer questions regarding the penetration into tissue sites, what constitutes therapeutic levels, and the mechanisms of action in the delay of viral rebound and post-rebound control before bnAb can become an important therapeutic advance for PWH. 


\section{AUTHOR CONTRIBUTIONS}

All authors reviewed the literature, drafted and revised the paper. All authors contributed to the article and approved the submitted version.

\section{FUNDING}

SV reports funding from the U.S. Department of Defense with Henry M. Jackson Foundation for the Advancement of Military Medicine (Cooperative agreement numbers W81XWH-11-20174, W81XWH-07-2-0067, W81XWH-18-2-0040), funding from the NIH/NIAID (1UM1AI126603, 2UM1AI108568-08),

\section{REFERENCES}

1. Palella FJJr., Baker RK, Moorman AC, Chmiel JS, Wood KC, Brooks JT, et al. Mortality in the Highly Active Antiretroviral Therapy Era: Changing Causes of Death and Disease in the HIV Outpatient Study. J Acquir Immune Defic Syndr (2006) 43(1):27-34. doi: 10.1097/01.qai.0000233310.90484.16

2. HIV-CAUSAL Collaboration, Ray M, Logan R, Sterne JA, Hernandez-Diaz S, Robins JM, et al. The Effect of Combined Antiretroviral Therapy on the Overall Mortality of HIV-Infected Individuals. AIDS (2010) 24(1):123-37. doi: 10.1097/QAD.0b013e3283324283

3. Chun TW, Stuyver L, Mizell SB, Ehler LA, Mican JA, Baseler M, et al. Presence of an Inducible HIV-1 Latent Reservoir During Highly Active Antiretroviral Therapy. Proc Natl Acad Sci USA (1997) 94(24):13193-7. doi: 10.1073/pnas.94.24.13193

4. Finzi D, Hermankova M, Pierson T, Carruth LM, Buck C, Chaisson RE, et al. Identification of a Reservoir for HIV-1 in Patients on Highly Active Antiretroviral Therapy. Science (1997) 278(5341):1295-300. doi: 10.1126/science.278.5341.1295

5. Chomont N, El-Far M, Ancuta P, Trautmann L, Procopio FA, Yassine-Diab B, et al. HIV Reservoir Size and Persistence Are Driven by T Cell Survival and Homeostatic Proliferation. Nat Med (2009) 15(8):893-900. doi: 10.1038/nm.1972

6. Li JZ, Etemad B, Ahmed H, Aga E, Bosch RJ, Mellors JW, et al. The Size of the Expressed HIV Reservoir Predicts Timing of Viral Rebound After Treatment Interruption. AIDS (2016) 30(3):343-53. doi: 10.1097/QAD.00000 00000000953

7. Namazi G, Fajnzylber JM, Aga E, Bosch RJ, Acosta EP, Sharaf R, et al. The Control of HIV After Antiretroviral Medication Pause (Champ) Study: Posttreatment Controllers Identified From 14 Clinical Studies. J Infect Dis (2018) 218(12):1954-63. doi: 10.1093/infdis/jiy479

8. Govindasamy D, Ford N, Kranzer K. Risk Factors, Barriers and Facilitators for Linkage to Antiretroviral Therapy Care: A Systematic Review. AIDS (2012) 26 (16):2059-67. doi: 10.1097/QAD.0b013e3283578b9b

9. Ortego C, Huedo-Medina TB, Llorca J, Sevilla L, Santos P, Rodriguez E, et al. Adherence to Highly Active Antiretroviral Therapy (HAART): A MetaAnalysis. AIDS Behav (2011) 15(7):1381-96. doi: 10.1007/s10461-011-9942-x

10. Shubber Z, Mills EJ, Nachega JB, Vreeman R, Freitas M, Bock P, et al. PatientReported Barriers to Adherence to Antiretroviral Therapy: A Systematic Review and Meta-Analysis. PloS Med (2016) 13(11):e1002183. doi: 10.1371/ journal.pmed.1002183

11. Dybul M, Attoye T, Baptiste S, Cherutich P, Dabis F, Deeks SG, et al. The Case for an HIV Cure and How to Get There. Lancet HIV (2021) 8(1):e51-8. doi: 10.1016/S2352-3018(20)30232-0

12. Beacroft L, Hallett TB. The Potential Impact of a "Curative Intervention" for HIV: A Modelling Study. Glob Health Res Policy (2019) 4:2. doi: 10.1186/ s41256-019-0107-1

13. Lewin SR, Attoye T, Bansbach C, Doehle B, Dube K, Dybul M, et al. MultiStakeholder Consensus on a Target Product Profile for an HIV Cure. Lancet HIV (2021) 8(1):e42-50. doi: 10.1016/S2352-3018(20)30234-4

14. Wu X, Yang ZY, Li Y, Hogerkorp CM, Schief WR, Seaman MS, et al. Rational Design of Envelope Identifies Broadly Neutralizing Human Monoclonal Antibodies to HIV-1. Science (2010) 329(5993):856-61. doi: 10.1126/ science. 1187659 and funding from the US Department of Defense (W81XWH1810579). DH reports funding from the U.S. Department of Defense with Henry M. Jackson Foundation for the Advancement of Military Medicine (Cooperative agreement number W81XWH-18-2-0040) and funding from the NIH/ NIAID (1UM1AI126603, 2UM1AI108568-08). JM reports funding from NIH/NIAID to the I4C Martin Delaney Collaboratory (UM1AI126603), to the Pitt-Ohio State Clinical Trials Unit (UM1 AI069494), to the Pitt Virology Specialty Laboratory (UM1 AI106701), to the University of Pittsburgh (U01AI131285 and U01AI152969), from NCI through Leidos (75N91019D00024), and from the Bill \& Melinda Gates Foundation (OPP1115715).

15. Ko SY, Pegu A, Rudicell RS, Yang ZY, Joyce MG, Chen X, et al. Enhanced Neonatal Fc Receptor Function Improves Protection Against Primate SHIV Infection. Nature (2014) 514(7524):642-5. doi: 10.1038/nature13612

16. Scheid JF, Mouquet H, Ueberheide B, Diskin R, Klein F, Oliveira TY, et al. Sequence and Structural Convergence of Broad and Potent HIV Antibodies That Mimic CD4 Binding. Science (2011) 333(6049):1633-7. doi: 10.1126/ science. 1207227

17. Gautam R, Nishimura Y, Gaughan N, Gazumyan A, Schoofs T, Buckler-White A, et al. A Single Injection of Crystallizable Fragment Domain-Modified Antibodies Elicits Durable Protection From SHIV Infection. Nat Med (2018) 24(5):610-6. doi: 10.1038/s41591-018-0001-2

18. Rudicell RS, Kwon YD, Ko SY, Pegu A, Louder MK, Georgiev IS, et al. Enhanced Potency of a Broadly Neutralizing HIV-1 Antibody In Vitro Improves Protection Against Lentiviral Infection In Vivo. J Virol (2014) 88 (21):12669-82. doi: 10.1128/JVI.02213-14

19. Huang J, Kang BH, Ishida E, Zhou T, Griesman T, Sheng Z, et al. Identification of a CD4-Binding-Site Antibody to HIV That Evolved NearPan Neutralization Breadth. Immunity (2016) 45(5):1108-21. doi: 10.1016/ j.immuni.2016.10.027

20. Sok D, van Gils MJ, Pauthner M, Julien JP, Saye-Francisco KL, Hsueh J, et al. Recombinant HIV Envelope Trimer Selects for Quaternary-Dependent Antibodies Targeting the Trimer Apex. Proc Natl Acad Sci USA (2014) 111 (49):17624-9. doi: 10.1073/pnas.1415789111

21. Doria-Rose NA, Schramm CA, Gorman J, Moore PL, Bhiman JN, DeKosky BJ, et al. Developmental Pathway for Potent V1V2-Directed HIVNeutralizing Antibodies. Nature (2014) 509(7498):55-62. doi: 10.1038/ nature 13036

22. Mouquet H, Scharf L, Euler Z, Liu Y, Eden C, Scheid JF, et al. Complex-Type N-Glycan Recognition by Potent Broadly Neutralizing HIV Antibodies. Proc Natl Acad Sci USA (2012) 109(47):E3268-77. doi: 10.1073/pnas.1217207109

23. Walker LM, Huber M, Doores KJ, Falkowska E, Pejchal R, Julien JP, et al. Broad Neutralization Coverage of HIV by Multiple Highly Potent Antibodies. Nature (2011) 477(7365):466-70. doi: 10.1038/nature10373

24. Huang J, Ofek G, Laub L, Louder MK, Doria-Rose NA, Longo NS, et al. Broad and Potent Neutralization of HIV-1 by a gp41-Specific Human Antibody. Nature (2012) 491(7424):406-12. doi: 10.1038/nature11544

25. Kwon YD, Georgiev IS, Ofek G, Zhang B, Asokan M, Bailer RT, et al. Optimization of the Solubility of HIV-1-Neutralizing Antibody 10E8 Through Somatic Variation and Structure-Based Design. J Virol (2016) 90 (13):5899-914. doi: 10.1128/JVI.03246-15

26. McCoy LE, Burton DR. Identification and Specificity of Broadly Neutralizing Antibodies Against HIV. Immunol Rev (2017) 275(1):11-20. doi: 10.1111/imr.12484

27. Sajadi MM, Dashti A, Rikhtegaran Tehrani Z, Tolbert WD, Seaman MS, Ouyang X, et al. Identification of Near-Pan-Neutralizing Antibodies Against HIV-1 by Deconvolution of Plasma Humoral Responses. Cell (2018) 173 (7):1783-1795 e14. doi: 10.1016/j.cell.2018.03.061

28. Liu Q, Zhang P, Miao H, Lin Y, Kwon YD, Kwong PD, et al. Rational Engraftment of Quaternary-Interactive Acidic Loops for Anti-HIV-1 Antibody Improvement. J Virol (2021) 95(12):e00159-21. doi: 10.1128/JVI.00159-21

29. Ledgerwood JE, Coates EE, Yamshchikov G, Saunders JG, Holman L, Enama ME, et al. Safety, Pharmacokinetics and Neutralization of the Broadly 
Neutralizing HIV-1 Human Monoclonal Antibody VRC01 in Healthy Adults. Clin Exp Immunol (2015) 182(3):289-301. doi: 10.1111/cei.12692

30. Caskey M, Klein F, Lorenzi JC, Seaman MS, West APJr., Buckley N, et al. Viraemia Suppressed in HIV-1-Infected Humans by Broadly Neutralizing Antibody 3BNC117. Nature (2015) 522(7557):487-91. doi: 10.1038/nature14411

31. Lynch RM, Boritz E, Coates EE, DeZure A, Madden P, Costner P, et al. Virologic Effects of Broadly Neutralizing Antibody VRC01 Administration During Chronic HIV-1 Infection. Sci Trans Med (2015) 7(319):319ra206319ra206. doi: 10.1126/scitranslmed.aad5752

32. Caskey M, Schoofs T, Gruell H, Settler A, Karagounis T, Kreider EF, et al. Antibody 10-1074 Suppresses Viremia in HIV-1-Infected Individuals. Nat Med (2017) 23(2):185. doi: 10.1038/nm.4268

33. Mayer KH, Seaton KE, Huang Y, Grunenberg N, Isaacs A, Allen M, et al. Safety, Pharmacokinetics, and Immunological Activities of Multiple Intravenous or Subcutaneous Doses of an anti-HIV Monoclonal Antibody, VRC01, Administered to HIV-Uninfected Adults: Results of a Phase 1 Randomized Trial. PloS Med (2017) 14(11):e1002435. doi: 10.1371/journal.pmed.1002435

34. Gaudinski MR, Coates EE, Houser KV, Chen GL, Yamshchikov G, Saunders JG, et al. Safety and Pharmacokinetics of the Fc-Modified HIV-1 Human Monoclonal Antibody VRC01LS: A Phase 1 Open-Label Clinical Trial in Healthy Adults. PloS Med (2018) 15(1):e1002493. doi: 10.1371/journal.pmed.1002493

35. Gaudinski MR, Houser KV, Doria-Rose NA, Chen GL, Rothwell RSS, Berkowitz N, et al. Safety and Pharmacokinetics of Broadly Neutralising Human Monoclonal Antibody VRC07-523LS in Healthy Adults: A Phase 1 Dose-Escalation Clinical Trial. Lancet HIV (2019) 6(10):e667-79. doi: 10.1016/S2352-3018(19)30181-X

36. Stephenson K, Julg B, Ansel J, Walsh SR, Tan CS, Maxfield L, et al. Therapeutic Activity of PGT121 Monoclonal Antibody in HIV-Infected Adults. In: Conference on Retroviruses and Opportunistic Infections (Croi) (2019).

37. Chen G, Coates E, Fichtenbaum C, Koletar S, Landovitz R, Presti R, et al. Safety and Virologic Effect of the HIV-1 Broadly Neutralizing Antibodies, VRC01LS or VRC07-523LS, Administered to HIV-Infected Adults in a Phase 1 Clinical Trial. In: Journal of the International Aids Society. SOUTHERN GATE, CHICHESTER PO19 8SQ, W: JOHN WILEY \& SONS LTD THE ATRIUM (2019).

38. Widge AT, Houser KV, Gaudinski MR, Chen G, Carter C, Hickman SP, et al. A Phase I Dose-Escalation Trial of Human Monoclonal Antibody N6LS in Healthy Adults. In: Conference on Retroviruses and Opportunistic Infections (Croi) (2020).

39. Koup RA. Review of bNAbs in Clinical Development. In: Hiv Research for Prevention Hivr4p, Satellite Session SA04 State of the Art of HIV bNAbs for Prevention of HIV Infection (2018).

40. Pegu A, Hessell AJ, Mascola JR, Haigwood NL. Use of Broadly Neutralizing Antibodies for HIV-1 Prevention. Immunol Rev (2017) 275(1):296-312. doi: 10.1111/imr.12511

41. Julg B, Barouch DH. Neutralizing Antibodies for HIV-1 Prevention. Curr Opin HIV AIDS (2019) 14(4):318. doi: 10.1097/COH.0000000000000556

42. Karuna ST, Corey L. Broadly Neutralizing Antibodies for HIV Prevention. Annu Rev Med (2020) 71:329-46. doi: 10.1146/annurev-med-110118-045506

43. Corey L, Gilbert PB, Juraska M, Montefiori DC, Morris L, Karuna ST, et al. Two Randomized Trials of Neutralizing Antibodies to Prevent HIV-1 Acquisition. N Engl J Med (2021) 384(11):1003-14. doi: 10.1056/NEJMoa2031738

44. Scheid JF, Horwitz JA, Bar-On Y, Kreider EF, Lu CL, Lorenzi JC, et al. HIV-1 Antibody 3BNC117 Suppresses Viral Rebound in Humans During Treatment Interruption. Nature (2016) 535(7613):556-60. doi: 10.1038/nature18929

45. Cohen YZ, Lorenzi JCC, Krassnig L, Barton JP, Burke L, Pai J, et al. Relationship Between Latent and Rebound Viruses in a Clinical Trial of anti-HIV-1 Antibody 3BNC117. J Exp Med (2018) 215(9):2311-24. doi: 10.1084/jem.20180936

46. Bar KJ, Sneller MC, Harrison LJ, Justement JS, Overton ET, Petrone ME, et al. Effect of HIV Antibody VRC01 on Viral Rebound After Treatment Interruption. N Engl J Med (2016) 375(21):2037-50. doi: 10.1056/NEJMoa1608243

47. Ananworanich J, Chomont N, Eller LA, Kroon E, Tovanabutra S, Bose M, et al. HIV DNA Set Point Is Rapidly Established in Acute HIV Infection and Dramatically Reduced by Early Art. EBioMedicine (2016) 11:68-72. doi: 10.1016/j.ebiom.2016.07.024

48. Archin NM, Vaidya NK, Kuruc JD, Liberty AL, Wiegand A, Kearney MF, et al. Immediate Antiviral Therapy Appears to Restrict Resting CD4+ Cell HIV-1 Infection Without Accelerating the Decay of Latent Infection. Proc Natl Acad Sci USA (2012) 109(24):9523-8. doi: 10.1073/pnas.1120248109
49. Cheret A, Bacchus-Souffan C, Avettand-Fenoel V, Melard A, Nembot G, Blanc C, et al. Combined ART Started During Acute HIV Infection Protects Central Memory CD4+ T Cells and Can Induce Remission. J Antimicrob Chemother (2015) 70(7):2108-20. doi: 10.1093/jac/dkv084

50. Delwart E, Magierowska M, Royz M, Foley B, Peddada L, Smith R, et al. Homogeneous Quasispecies in 16 Out of 17 Individuals During Very Early HIV-1 Primary Infection. AIDS (2002) 16(2):189-95. doi: 10.1097/00002030200201250-00007

51. Altfeld M, Rosenberg ES, Shankarappa R, Mukherjee JS, Hecht FM, Eldridge RL, et al. Cellular Immune Responses and Viral Diversity in Individuals Treated During Acute and Early HIV-1 Infection. J Exp Med (2001) 193 (2):169-80. doi: 10.1084/jem.193.2.169

52. Crowell TA, Colby DJ, Pinyakorn S, Sacdalan C, Pagliuzza A, Intasan J, et al. Safety and Efficacy of VRC01 Broadly Neutralising Antibodies in Adults With Acutely Treated HIV (RV397): A Phase 2, Randomised, Double-Blind, Placebo-Controlled Trial. Lancet HIV (2019) 6(5):e297-306. doi: 10.1016/ S2352-3018(19)30053-0

53. Cale EM, Bai H, Bose M, Messina MA, Colby DJ, Sanders-Buell E, et al. Neutralizing Antibody VRC01 Failed to Select for HIV-1 Mutations Upon Viral Rebound. J Clin Invest (2020) 130(6):3299-304. doi: 10.1172/JCI134395

54. Zalevsky J, Chamberlain AK, Horton HM, Karki S, Leung IW, Sproule TJ, et al. Enhanced Antibody Half-Life Improves In Vivo Activity. Nat Biotechnol (2010) 28(2):157-9. doi: 10.1038/nbt.1601

55. Gautam R, Nishimura Y, Pegu A, Nason MC, Klein F, Gazumyan A, et al. A Single Injection of Anti-HIV-1 Antibodies Protects Against Repeated SHIV Challenges. Nature (2016) 533(7601):105-9. doi: 10.1038/nature17677

56. Dall'Acqua WF, Kiener PA, Wu H. Properties of Human IgG1s Engineered for Enhanced Binding to the Neonatal Fc Receptor (Fcrn). J Biol Chem (2006) 281(33):23514-24. doi: 10.1074/jbc.M604292200

57. Yu X-Q, Robbie GJ, Wu Y, Esser MT, Jensen K, Schwartz HI, et al. Safety, Tolerability, and Pharmacokinetics of MEDI4893, an Investigational, Extended-Half-Life, Anti-Staphylococcus Aureus Alpha-Toxin Human Monoclonal Antibody, in Healthy Adults. Antimicrob Agents Chemother (2017) 61(1):e01020-16. doi: 10.1128/AAC.01020-16

58. Doria-Rose NA, Bhiman JN, Roark RS, Schramm CA, Gorman J, Chuang GY, et al. New Member of the V1V2-Directed Cap256-Vrc26 Lineage That Shows Increased Breadth and Exceptional Potency. J Virol (2016) 90(1):76-91. doi: 10.1128/JVI.01791-15

59. Reeves J, Zheng Y, Olefsky M, Lie Y, Burke L, Taiwo B, et al. Susceptibility to BnAbs Is Concordant in Pre-ART Plasma and On-ART Pbmcs: ACTG Nwc413. In: Conference on Retroviruses and Opportunistic Infections (Croi) (2019).

60. Bar-On Y, Gruell H, Schoofs T, Pai JA, Nogueira L, Butler AL, et al. Safety and Antiviral Activity of Combination HIV-1 Broadly Neutralizing Antibodies in Viremic Individuals. Nat Med (2018) 24(11):1701. doi: 10.1038/s41591-018-0186-4

61. Mendoza P, Gruell H, Nogueira L, Pai JA, Butler AL, Millard K, et al. Combination Therapy With Anti-HIV-1 Antibodies Maintains Viral Suppression. Nature (2018) 561(7724):479. doi: 10.1038/s41586-018-0531-2

62. Kong R, Louder MK, Wagh K, Bailer RT, deCamp A, Greene K, et al. Improving Neutralization Potency and Breadth by Combining Broadly Reactive HIV-1 Antibodies Targeting Major Neutralization Epitopes. J Virol (2015) 89(5):2659-71. doi: 10.1128/JVI.03136-14

63. Wagh K, Seaman MS, Zingg M, Fitzsimons T, Barouch DH, Burton DR, et al. Potential of Conventional \& Bispecific Broadly Neutralizing Antibodies for Prevention of HIV-1 Subtype A, C \& D Infections. PloS Pathog (2018) 14(3): e1006860. doi: 10.1371/journal.ppat.1006860

64. Cohen YZ, Butler AL, Millard K, Witmer-Pack M, Levin R, Unson-O’Brien C, et al. Safety, Pharmacokinetics, and Immunogenicity of the Combination of the Broadly Neutralizing Anti-HIV-1 Antibodies 3BNC117 and 10-1074 in Healthy Adults: A Randomized, Phase 1 Study. PloS One (2019) 14(8): e0219142. doi: 10.1371/journal.pone.0219142

65. Huang Y, Yu J, Lanzi A, Yao X, Andrews CD, Tsai L, et al. Engineered Bispecific Antibodies With Exquisite HIV-1-Neutralizing Activity. Cell (2016) 165(7):1621-31. doi: 10.1016/j.cell.2016.05.024

66. Xu L, Pegu A, Rao E, Doria-Rose N, Beninga J, McKee K, et al. Trispecific Broadly Neutralizing HIV Antibodies Mediate Potent SHIV Protection in Macaques. Science (2017) 358(6359):85-90. doi: 10.1126/science.aan8630 
67. Nishimura Y, Gautam R, Chun TW, Sadjadpour R, Foulds KE, Shingai M, et al. Early Antibody Therapy Can Induce Long-Lasting Immunity to SHIV. Nature (2017) 543(7646):559-63. doi: 10.1038/nature21435

68. Nishimura Y, Donau OK, Dias J, Ferrando-Martinez S, Jesteadt E, Sadjadpour $\mathrm{R}$, et al. Immunotherapy During the Acute SHIV Infection of Macaques Confers Long-Term Suppression of Viremia. J Exp Med (2021) 218(1): e20201214. doi: 10.1084/jem.20201214

69. Borducchi EN, Liu J, Nkolola JP, Cadena AM, Yu WH, Fischinger S, et al. Antibody and TLR7 Agonist Delay Viral Rebound in SHIV-Infected Monkeys. Nature (2018) 563(7731):360-4. doi: 10.1038/s41586-018-0600-6

70. Hsu DC, Schuetz A, Imerbsin R, Silsorn D, Pegu A, Inthawong D, et al. TLR7 Agonist, N6-LS and PGT121 Delayed Viral Rebound in SHIV-Infected Macaques After Antiretroviral Therapy Interruption. PloS Pathog (2021) 17 (2):e1009339. doi: 10.1371/journal.ppat.1009339

71. Barouch D, Mercado N, Chandrashekar A, Borducchi E, Nkolola J, Carr BA, et al. PGT121 and Vesatolimod in Chronically Treated SHIV-Infected Rhesus Monkeys. In: Conference on Retroviruses and Opportunistic Infections (2020).

72. Lim SY, Osuna CE, Lee J, Silva-Ayala D, Vikhe P, Chen E, et al. Combination IL-15 Therapy in a SHIV Nhp Model. In: . Conference on Retroviruses and Opportunistic Infections (2020).

73. Barouch D, Mercado N, Chandrashekar A, Borducchi E, Nkolola J, Pau M, et al. Combined ACTIVE and PASSIVE Immunization IN SHIV-Infected RHESUS Monkeys. In: Conference on Retroviruses and Opportunistic Infections (2020).

74. Niessl J, Baxter AE, Mendoza P, Jankovic M, Cohen YZ, Butler AL, et al. Combination Anti-HIV-1 Antibody Therapy Is Associated With Increased Virus-Specific T Cell Immunity. Nat Med (2020) 26(2):222-7. doi: 10.1038/ s41591-019-0747-1

75. Riddler SA, Zheng L, Durand CM, Ritz J, Koup RA, Ledgerwood J, et al. Randomized Clinical Trial to Assess the Impact of the Broadly Neutralizing HIV-1 Monoclonal Antibody VRC01 on HIV-1 Persistence in Individuals on Effective Art. Open Forum Infect Dis (2018) 5(10):ofy242. doi: 10.1093/ofid/ofy242

76. Hemmi H, Kaisho T, Takeuchi O, Sato S, Sanjo H, Hoshino K, et al. Small AntiViral Compounds Activate Immune Cells Via the TLR7 MyD88-Dependent Signaling Pathway. Nat Immunol (2002) 3(2):196-200. doi: 10.1038/ni758

77. Bam RA, Hansen D, Irrinki A, Mulato A, Jones GS, Hesselgesser J, et al. Tlr7 Agonist Gs-9620 Is a Potent Inhibitor of Acute HIV-1 Infection in Human Peripheral Blood Mononuclear Cells. Antimicrob Agents Chemother (2017) 61 (1):e01369-16. doi: 10.1128/AAC.01369-16

78. Ellis-Connell AL, Balgeman AJ, Zarbock KR, Barry G, Weiler A, Egan JO, et al. Alt-803 Transiently Reduces Simian Immunodeficiency Virus Replication in the Absence of Antiretroviral Treatment. J Virol (2018) 92 (3):e01748-17. doi: 10.1128/JVI.01748-17

79. Webb GM, Molden J, Busman-Sahay K, Abdulhaqq S, Wu HL, Weber WC, et al. The Human IL-15 Superagonist N-803 Promotes Migration of VirusSpecific CD8+ T and NK Cells to B Cell Follicles But Does Not Reverse Latency in ART-Suppressed, SHIV-Infected Macaques. PloS Pathog (2020) 16 (3):e1008339. doi: 10.1371/journal.ppat.1008339

80. McBrien JB, Mavigner M, Franchitti L, Smith SA, White E, Tharp GK, et al. Robust and Persistent Reactivation of SIV and HIV by N-803 and Depletion of CD8(+) Cells. Nature (2020) 578(7793):154-9. doi: 10.1038/s41586-020-1946-0

81. Shirakawa K, Chavez L, Hakre S, Calvanese V, Verdin E. Reactivation of Latent HIV by Histone Deacetylase Inhibitors. Trends Microbiol (2013) 21 (6):277-85. doi: 10.1016/j.tim.2013.02.005
82. Gruell H, Cohen Y, Gunst J. A Randomized Trial of the Impact of 3BNC117 and Romidepsin on the HIV-1 Reservoir. In: Conference on Retroviruses and Opportunistic Infections (Croi) (2020).

83. Swindells S, Andrade-Villanueva J-F, Richmond GJ, Rizzardini G, Baumgarten A, Masiá M, et al. Long-Acting Cabotegravir and Rilpivirine for Maintenance of HIV-1 Suppression. New Engl J Med (2020) 382 (12):1112-23. doi: 10.1056/NEJMoa1904398

84. Segal-Maurer S, Castagna A, Berhe M, Richmond G, Ruane PJ, Sinclair GI, et al. Potent Antiviral Acitivity of Lenacapavir in Phase 2/3 in Heavily ArtExperienced Pwh. In: Conference on Retroviruses and Opportunistic Infections (2021).

85. Rolland M, Tovanabutra S, Dearlove B, Li Y, Owen CL, Lewitus E, et al. Molecular Dating and Viral Load Growth Rates Suggested That the Eclipse Phase Lasted About a Week in HIV-1 Infected Adults in East Africa and Thailand. PloS Pathog (2020) 16(2):e1008179. doi: 10.1371/journal. ppat.1008179

86. Julg B, Dee L, Ananworanich J, Barouch DH, Bar K, Caskey M, et al. Recommendations for Analytical Antiretroviral Treatment Interruptions in HIV Research Trials-Report of a Consensus Meeting. Lancet HIV (2019) 6(4): e259-68. doi: 10.1016/S2352-3018(19)30052-9

87. Dawson L. Human Immunodeficiency Virus Transmission Risk in Analytical Treatment Interruption Studies: Relational Factors and Moral Responsibility. J Infect Dis (2019) 220(220 Suppl 1):S12-5. doi: 10.1093/infdis/jiz090

88. Henderson GE, Peay HL, Kroon E, Cadigan RJ, Meagher K, Jupimai T, et al. Ethics of Treatment Interruption Trials in HIV Cure Research: Addressing the Conundrum of Risk/Benefit Assessment. J Med Ethics (2018) 44(4):270-6. doi: 10.1136/medethics-2017-104433

89. Eyal N, Holtzman LG, Deeks SG. Ethical Issues in HIV Remission Trials. Curr Opin HIV AIDS (2018) 13(5):422-7. doi: 10.1097/COH.0000000000000489

Disclaimer: The U.S. Military HIV Research Program (MHRP) and the Emerging Infectious Diseases Branch (EIDB) at the Walter Reed Army Institute of Research are supported through a cooperative agreement with the Henry M. Jackson Foundation for the Advancement of Military Medicine (HJF). The views expressed are those of the authors and should not be construed to represent the positions of the U.S. Army, the Department of Defense or the Henry M. Jackson Foundation for the Advancement of Military Medicine, Inc.

Conflict of Interest: SV and DH report grants from the U.S. Department of Defense with Henry M. Jackson Foundation for the Advancement of Military Medicine and grants from the NIH/NIAID for the submitted work. SV also report grants from the U.S. Department of Defense. JM reports grants from the NIH for the submitted work, and grants from Gilead Sciences, Janssen Pharmaceuticals, USAID, and personal fees from Accelevir Diagnostics, Gilead Sciences, Merck, Xi'an Yufan Biotechnologies, and other from Infectious Diseases Connect, CoCrystal Pharmaceuticals, Inc., and Abound Bio, Inc., outside the submitted work.

Copyright (c) $2021 \mathrm{Hsu}$, Mellors and Vasan. This is an open-access article distributed under the terms of the Creative Commons Attribution License (CC BY). The use, distribution or reproduction in other forums is permitted, provided the original author(s) and the copyright owner (s) are credited and that the original publication in this journal is cited, in accordance with accepted academic practice. No use, distribution or reproduction is permitted which does not comply with these terms. 